\title{
Anthelmintic constituents of Clonostachys candelabrum
}

\author{
Sloan Ayers ${ }^{1}$, Deborah L Zink ${ }^{1}$, Kenneth Mohn ${ }^{2,5}$, Joanne S Powell ${ }^{2}$, Christine M Brown ${ }^{2}$, Gerald Bills ${ }^{3}$, \\ Alan Grund ${ }^{4}$, Donald Thompson ${ }^{2}$ and Sheo B Singh ${ }^{1}$
}

Five diastereomeric polyketide glycosides, roselipins 3A-3E (1-5), have been isolated from the acetone extract of Clonostachys candelabrum on the basis of their positive anthelmintic activity. The structures of these compounds were elucidated by comparison of their NMR and MS data to those of previously reported roselipins and related structures, and were confirmed by 2D-NMR spectral analysis. Known compounds linoleic acid (6) and aurantiogliocladin (7) were also isolated as active anthelmintic components, although much less potent than the roselipins.

The Journal of Antibiotics (2010) 63, 119-122; doi:10.1038/ja.2009.131; published online 15 January 2010

Keywords: acyl glycoside; anthelmintic; candelabrum; Clonostachys; fungal; natural product; TMC

\section{INTRODUCTION}

Internal parasitic infection is a great threat to the productivity of the sheep and goat industry. Tremendous progress has been made in the development of anthelmintic drugs in the past 50 years. During this period, the current classes of synthetic drugs were developed, including the benzimidazoles and imidazothiazoles (such as levamisole). Another major step was achieved with the introduction of the avermectin class of macrolactones in the early 1980s. The discovery of this compound class led to anthelmintic drugs, such as ivermectin and doramectin, which have excellent broad-spectrum activity and superior potency. However, resistance to all of these classes of drugs has been observed, leading to the continuing need for further research to discover new classes of anthelmintics, especially those with novel modes of action. ${ }^{1}$

Our strategy has been to screen extracts of bacterial and fungal fermentations as well as plants for in vitro activity against Haemonchus contortus, ${ }^{2}$ which is one of the most prevalent parasitic worms that infect sheep and goats. The in vitro activities were then assayed in vivo against Heligmosomoides polygyrus in mice. ${ }^{3}$ This strategy led to discoveries of a number of natural products from microbial and plant origins. ${ }^{4-10}$ Continued efforts led to identification of an acetone extract of Clonostachys candelabrum that showed in vitro activity and was selected for further fractionation. Bioassay-guided fractionation using the $H$. contortus assay led to the isolation of active anthelmintics 1-7 (Figure 1).

\section{RESULTS AND DISCUSSION}

Compounds 1-7 were isolated from an acetone extract of a solid fermentation of C. candelabrum by solvent partitioning, Sephadex
LH-20 (GE Healthcare, Uppsala, Sweden) column chromatography, and finally preparative and semipreparative reversed-phase HPLC. Compounds 1-5 were separated from 6 and 7 by Sephadex LH20 chromatography. Compounds $\mathbf{1}$ and $\mathbf{2}$ were separated from $\mathbf{3}$ to $\mathbf{5}$ without much difficulty by preparative reversed-phase HPLC; however, separation of diastereomeric 1 from 2 was not possible under reversed-phase conditions. Separation of the diastereomeric mixture of 3-5 was also not possible (see experimental section for details).

Compound 6 was a clear oil that showed a peak at $\mathrm{m} / \mathrm{z} 279$ $[\mathrm{M}-\mathrm{H}]^{-}$by low-resolution MS, and end absorbance in the UV. Its ${ }^{1} \mathrm{H}$ NMR spectrum was compared with that of purchased linoleic acid and was found to be identical.

Compound 7 was an orange solid that showed a peak at $m / z 197$ $[\mathrm{M}+\mathrm{H}]^{+}$by low-resolution MS, gave a strong absorbance at $278 \mathrm{~nm}$ and a very weak absorbance at $\sim 410 \mathrm{~nm}$ by UV (from HPLC-Diode Array Detector, Agilent, Santa Clara, CA, USA). The ${ }^{1} \mathrm{H}$ NMR showed two singlets of equal integration at $\delta_{\mathrm{H}} 3.99$ and $2.00\left(\mathrm{CDCl}_{3}\right)$ which, combined with the MS data, matched literature data for aurantiogliocladin. ${ }^{11,12}$ The ${ }^{13} \mathrm{C}$ NMR consisted of five signals at $\delta_{\mathrm{C}} 184.3,144.4$, 138.9, 61.2 and 12.1, also matching literature data. ${ }^{12}$

The NMR, MS and UV spectra for the mixture of 1-2 were nearly identical to the mixture of 3-5. ${ }^{1} \mathrm{H}$ NMR features for $\mathbf{1 - 5}$ included alkene doublets at approximately $\delta_{\mathrm{H}} 6.60,5.20,5.15$ and 5.10, all with coupling constants of $8.5-10 \mathrm{~Hz}$. The downfield alkene signal was due to conjugation with a carbonyl. Multiple methyl doublets were present between $\delta_{\mathrm{H}} 0.65$ and 0.90 along with four methyl singlets (three between $\delta_{\mathrm{H}} 1.49$ and 1.55 and the fourth from $\delta_{\mathrm{H}} 1.77$ to 1.78). The presence of a sugar residue was evident by the presence of an anomeric signal at approximately $\delta_{\mathrm{H}} 4.14$, and multiple other

\footnotetext{
${ }^{1}$ Natural Products Chemistry, Merck Research Laboratories, Rahway, NJ, USA; ${ }^{2}$ Merck and Co. Inc., Branchburg Farm, Somerville, NJ, USA; ${ }^{3}$ CIBE, Merck, Sharp \& Dohme de España, Madrid, Spain and ${ }^{4}$ Bio-Technical Resources, Manitowoc, WI, USA

${ }^{5}$ Current address: Elanco Animal Health, 2001 W. Main St, PO Box 708, Greenfield, IN 46140, USA.

Correspondence: Dr SB Singh, Natural Products Chemistry, Merck Research Laboratories, PO Box 2000, 126 E Lincoln Avenue, Rahway, NJ 07065, USA.

E-mail: sheo_singh@merck.com

Received 13 October 2009; revised 10 December 2009; accepted 11 December 2009; published online 15 January 2010
} 
<smiles></smiles>

mixture of 1 and $\mathbf{2}$ :<smiles>O=C(F)[C@@H](O)[C@@H](O)[C@H](O)CO</smiles><smiles>O=C[C@H](O)[C@@H](O)[C@H](O)C(F)=CO</smiles>

mixture of 3-5:<smiles>OC[C@@H](O)C(O)[C@H](O)CO</smiles><smiles>OC[C@H](O)[C@@H](O)[C@H](O)CO</smiles><smiles>O=C(O)[C@@H](O)[C@@H](O)CO</smiles><smiles>CCCCC/C=C\C/C=C\CCCCCCCC(=O)O</smiles>

linoleic acid (6)<smiles>COC1=C(OC)C(=O)C(C)=C(C)C1=O</smiles>

aurantiogliocladin (7)

Figure 1 Chemical structures of compounds 1-7.

oxygenated methine signals between $\delta_{\mathrm{H}} 2.85$ and 4.0. The ${ }^{13} \mathrm{C}$ NMR spectrum showed presence of a carbonyl group between $\delta_{\mathrm{C}} 167$ and 168 for all compounds, as well as eight alkene carbons from $\delta_{\mathrm{C}} 126$ to 147 . The anomeric carbon of the sugar residue resonated at approximately $\delta_{\mathrm{C}}$ 96. Numerous oxygenated carbon signals were present from $\delta_{\mathrm{C}} 60$ to 82 in the ${ }^{13} \mathrm{C}$ NMR spectrum supporting the observed ${ }^{1} \mathrm{H}$ NMR assignments.

The MS data showed 1-5 to have the same formula, $\mathrm{C}_{40} \mathrm{H}_{70} \mathrm{O}_{14}$, and combined with the NMR data, the class of compound was determined to be the TMC $151^{13} / 154^{14} / 171^{14}$ and roselipin ${ }^{15-17}$ antibiotics. These compounds contain a propionate polyketide chain glycosylated with a mannose, and a sugar alcohol (mannitol or arabinitol) esterified to the polyketide chain. The formulae for 1-5 along with comparison of NMR spectrum indicated that the sugar alcohol present was arabinitol. Cladionol A is another compound in this class, except that the order of hydroxyl groups and alkenes in the polyketide backbone is reversed (the double bonds are between $\mathrm{C}-4 / \mathrm{C}$ 5, C-8/C-9 and C-12/C-13). ${ }^{18}$ Compounds $\mathbf{1 - 5}$ are distinguished from cladionol A by the downfield $\alpha, \beta$-unsaturated proton signal at $\delta_{\mathrm{H}}$ 6.6-6.7 for $\mathrm{H}-3$.

The mixture of $\mathbf{1}$ and $\mathbf{2}$ have the molecular formula of $\mathrm{C}_{40} \mathrm{H}_{70} \mathrm{O}_{14}$, which was deduced from the molecular ion of $792.5088\left[\mathrm{M}+\mathrm{NH}_{4}\right]^{+}$in the HPLC-ESIHRFTMS. Compound 1 (or 2) was identical to TMC154, except that the latter has a methyl ether at O-4 of the mannose. ${ }^{14}$ These compounds are also identical to the TMC-171 compounds (A, $\mathrm{B}$ and $\mathrm{C}$ ), except that $\mathbf{1}$ and $\mathbf{2}$ contain arabinitol instead of mannitol. ${ }^{14}$ Compounds 1 and 2 are also the 14,15-dehydro derivatives of TMC$151 \mathrm{D}$ and roselipin $1 \mathrm{~A} / \mathrm{B}^{13,15-17}$
Compounds 3-5 had the same molecular formula as $\mathbf{1}$ and 2, $\mathrm{C}_{40} \mathrm{H}_{70} \mathrm{O}_{14}$, which was deduced from the molecular ion of 792.5095 $\left[\mathrm{M}+\mathrm{NH}_{4}\right]^{+}$in the HPLC-ESIHRFTMS of the mixture. The only difference in the ${ }^{1} \mathrm{H}$ NMR data of 3-5 versus 1-2 was in the region of $\delta_{\mathrm{H}} 4-5$. The mixture of compounds 1 and 2 showed two doublets of doublets at $\delta_{\mathrm{H}} 4.3(J=11.0,2.5 \mathrm{~Hz})$ and $4.0(J=11.0,6.5 \mathrm{~Hz})$. These protons also showed heteronuclear multiple bond coherence correlation to the carbonyl carbon, which indicated that these protons were adjacent to the ester oxygen. For compounds 3-5, these proton signals were not present, instead having new signals at $\delta_{\mathrm{H}} 5.00$ (ddd), 4.82 (dd, $J=7.5,2.0 \mathrm{~Hz}$ ) and 4.78 (ddd), respectively, all integrating for approximately one-third of a proton. These signals indicated derivatives that were esterified at the secondary hydroxyl groups as opposed to the primary hydroxyl group as in $\mathbf{1}$ and $\mathbf{2}$. The multiplicity for the $\delta_{\mathrm{H}} 4.82$ signal indicated that it was the derivative esterified at $\mathrm{O}-3^{\prime}$.

Compounds 1-7 were evaluated for in vitro anthelmintic activity by the $H$. contortus assay as previously described. ${ }^{2}$ Compounds $\mathbf{1 - 5}$ were assayed as a mixture, and reduced motility of L3 larvae with an $\mathrm{EC}_{90}$ (effective concentration that reduced larval motility by 90\%) of $22 \mu \mathrm{g} \mathrm{ml}^{-1}$. Ivermectin was used as the positive control, and was more potent by approximately two orders of magnitude $\left(\mathrm{EC}_{90}\right.$ $0.18 \mu \mathrm{g} \mathrm{ml}^{-1}$ ). Linoleic acid (6) and aurantiogliocladin (7) exhibited $\mathrm{EC}_{90}$ values of 930 and $420 \mu \mathrm{g} \mathrm{ml}^{-1}$, respectively. The mixture of 1 and 2 was assayed in vivo against $H$. polygyrus in mice, resulting in a $16 \%$ reduction in worm count when dosed intramuscularly at $50 \mathrm{mg} \mathrm{kg}^{-1}$ when compared with negative control. They were not tested orally. The positive control was ivermectin $(81 \%$ reduction in worm count at $5 \mathrm{mg} \mathrm{kg}^{-1}$ intramuscularly). 
Roselipins have been reported ${ }^{15-17}$ as selective inhibitors ( $\mathrm{IC}_{50}$ $30-50 \mu \mathrm{M}$ ) of diacylglycerol acyl transferase $2 .{ }^{19}$ Increased diacylglycerol acyl transferase 2 activity in the liver causes hepatic steatosis, whereas diacylglycerol acyl transferase 1 is known to have a role in very low-density lipoprotein. TMC-151F was reported to show cytotoxicity against several tumor cell lines. ${ }^{13,14}$ Roselipin 2A and 2B inhibited HIV-1 integrase with an $\mathrm{IC}_{50}$ value of $8.5 \mu \mathrm{m} .{ }^{20}$

In summary, we have isolated a mixture of five new roselipin derivatives, all differentiated by the position at which the polyketide chain was esterified to the arabinitol residue. Previous reported compounds in this class with the arabinitol moiety have always been esterified at the terminal oxygens; only the derivatives having a mannitol residue were esterified at the secondary hydroxyl groups. It is possible that compounds $\mathbf{1}$ and/or $\mathbf{2}$ are the naturally synthesized diastereomers, and 3-5 are artifacts formed as the result of transesterification. Linoleic acid (6) and aurantiogliocladin (7) were also isolated, but were much less potent than the roselipins. This is the first report of the anthelmintic activity of the roselipin antibiotics.

\section{METHODS}

\section{General experimental procedures}

All reagents were obtained from Sigma-Aldrich (St Louis, MO, USA) and were used without further purification. IR data were obtained on a Perkin-Elmer Spectrum One (Perkin Elmer, Waltham, MA, USA). UV/Visble spectra were taken on a Perkin-Elmer Lambda 35 UV/Visible spectrometer (Perkin Elmer). NMR spectra were obtained on a Varian Inova $500 \mathrm{MHz}$ spectrometer (Varian, Palo Alto, CA, USA) operating at $500 \mathrm{MHz}$ for ${ }^{1} \mathrm{H}(\delta 2.49)$ and $125 \mathrm{MHz}$ for ${ }^{13} \mathrm{C}(\delta 39.5)$, nuclei and solvent shifts were used for internal standard. Low-resolution mass spectra were obtained on an Agilent MSD (Agilent), and high-resolution mass spectra were obtained on a Thermo Finnigan LTQ-FT (Thermo Fisher Scientific, Waltham, MA, USA) with the standard Ion Max API source (without the sweep cone) and ESI probe. Swiss Webster mice were obtained from Taconic Labs, Germantown, NY, USA. Ivermectin was used as the commercial product Ivomec Injection (1\%) for Cattle and Swine (Merial, Duluth, GA, USA). Linoleic acid was obtained from Sigma-Aldrich.

\section{Producing organism and fermentation}

Clonostachys candelabrum (F-146319) was recovered from decaying leaves collected in Los Sauces, La Palma, Canary Islands, Spain. The fungus was isolated by a particle-washing technique previously described. ${ }^{21}$ The fungus was identified from microscopic and cultural features ${ }^{22}$ and was maintained on plates of potato dextrose agar (Difco, Lawrence, KS, USA) at $22^{\circ} \mathrm{C}$. Agar plugs were used to inoculate $250 \mathrm{ml}$ baffled flasks containing $50 \mathrm{ml}$ seed medium, which consisted of corn steep liquor $\left(5 \mathrm{gl}^{-1}\right)$, tomato paste $\left(40 \mathrm{gl}^{-1}\right)$, oat flour $\left(10 \mathrm{gl}^{-1}\right)$, glucose $\left(10 \mathrm{gl}^{-1}\right)$ and a trace element mix $\left(10 \mathrm{mll}^{-1}\right)$. The trace element mix consisted of $\mathrm{FeSO}_{4} 7 \mathrm{H}_{2} \mathrm{O}\left(1 \mathrm{gl}^{-1}\right), \mathrm{MnSO}_{4} 4 \mathrm{H}_{2} \mathrm{O}\left(1 \mathrm{gl}^{-1}\right), \mathrm{CuCl}_{2} 2$ $\mathrm{H}_{2} \mathrm{O}\left(25 \mathrm{mgl}^{-1}\right), \mathrm{CaCl}_{2}\left(100 \mathrm{mgl}^{-1}\right), \mathrm{H}_{3} \mathrm{BO}_{3}\left(56 \mathrm{mgl}^{-1}\right),\left(\mathrm{NH}_{4}\right)_{6} \mathrm{Mo}_{7} \mathrm{O}_{24} 4-$ $\mathrm{H}_{2} \mathrm{O}\left(19 \mathrm{mgl}^{-1}\right)$ and $\mathrm{ZnSO}_{4} 7 \mathrm{H}_{2} \mathrm{O}\left(200 \mathrm{mgl}^{-1}\right)$, adjusted to $\mathrm{pH}$ 6.8. The flasks were incubated at $28^{\circ} \mathrm{C}$ at 220 r.p.m. for 4 days.

The production phase was prepared on a solid medium in $250 \mathrm{ml}$ Erlenmeyer flasks containing $14 \mathrm{~g}$ of millet seeds (Panicum miliaceum) with $30 \mathrm{ml}$ of a liquid nutrient solution poured over it. The liquid nutrient solution consisted of yeast extract $\left(16.7 \mathrm{gl}^{-1}\right)$, sucrose $\left(16.7 \mathrm{gl}^{-1}\right)$, alfalfa $\left(16.7 \mathrm{gl}^{-1}\right)$, sodium tartrate $\left(3.33 \mathrm{gl}^{-1}\right)$, corn oil $\left(3.33 \mathrm{mll}^{-1}\right)$ and $\mathrm{FeSO}_{4} 7 \mathrm{H}_{2} \mathrm{O}\left(0.33 \mathrm{gl}^{-1}\right)$, with no $\mathrm{pH}$ adjustment. After inoculation, flasks were incubated without shaking at $22{ }^{\circ} \mathrm{C}$ for 28 days. Solid cultures were harvested with a spatula and stored at $-20^{\circ} \mathrm{C}$ before extraction.

\section{Extraction and isolation}

Fungal material (2l) was initially shaken with $2 \mathrm{l}$ of acetone for $3 \mathrm{~h}$. The mixture was filtered and the residual solids were extracted with 11 of 1:1 MeOH/2butanone. The mixture was filtered and combined with the acetone extract, and evaporated under reduced pressure to $\sim 500 \mathrm{ml}$ of aqueous solution. The aqueous solution was partitioned with an equal volume of hexanes, then with two equal portions of $\mathrm{CHCl}_{3}$. Both hexanes and $\mathrm{CHCl}_{3}$ extracts were separately concentrated under reduced pressure to yield 3.5 and $11.5 \mathrm{~g}$ of gums, respectively. The hexane extract was inactive and was not pursued. A portion (3.1 g) of the active $\mathrm{CHCl}_{3}$ soluble material was brought up in $20 \mathrm{ml}$ of $\mathrm{MeOH}$ and loaded onto a 21 Sephadex LH-20 column. The column was eluted with $\mathrm{MeOH}$ at $10 \mathrm{ml} \mathrm{min}{ }^{-1}$. The first $300 \mathrm{ml}$ of $\mathrm{MeOH}$ was collected as one fraction followed by $2 \mathrm{~min}$ each fraction. Total elution volume of $\mathrm{MeOH}$ was 2.31 . Compounds 1-5 eluted in fractions 29-38, which were combined and evaporated to give $1.00 \mathrm{~g}$ of white powder. Compound 6 eluted in fractions 39-54 ( $1.46 \mathrm{~g}$ of clear oil), and 7 eluted in fractions $55-61$ (79 $\mathrm{mg}$ of orange solid). The combined fraction 29-38 was brought up in $8 \mathrm{ml}$ of $\mathrm{MeOH}$ and injected in eight 1-ml injections onto preparative HPLC (Waters, Milford, MA, USA) XTerra RP C ${ }_{18}, 300 \times 19 \mathrm{~mm}, 7 \mu \mathrm{m}, 10 \mathrm{ml} \mathrm{min}^{-1}, 25-90 \% \mathrm{MeCN}$ in $\mathrm{H}_{2} \mathrm{O}$, both containing $0.1 \%$ TFA, gradient time $40 \mathrm{~min}$ and UV detection at $210 \mathrm{~nm}$. Fractions 60-66 were lyophilized to afford $139.6 \mathrm{mg}$ of compounds $\mathbf{3 - 5}$, and fractions $67-74$ were similarly lyophilized to give $454.8 \mathrm{mg}$ of compounds 1-2 both as powder.

\section{Roselipins 3A and 3B $(1,2)$}

White solid: IR (ZnSe film) $v_{\max } 3348,2958,2922,2871,1671,1642,1453$, $1373,1312,1225,1063,1025,944,868,798,750 \mathrm{~cm}^{-1}$; UV (MeOH) $\lambda_{\max }(\log \varepsilon)$ 202 (4.43), 220 (sh, $\sim 4.12) \mathrm{nm} ;{ }^{1} \mathrm{H}-\mathrm{NMR}$ (DMSO- $\left.d_{6}, 500 \mathrm{MHz}\right) \delta 6.66$ and $6.64(1 \mathrm{H}, \mathrm{dq}, J=10.0,1.5 \mathrm{~Hz}, \mathrm{H}-3), 5.23(1 \mathrm{H}, \mathrm{d}, J=8.5 \mathrm{~Hz}, \mathrm{H}-11), 5.18(1 \mathrm{H}, \mathrm{d}$, $J=9.0 \mathrm{~Hz}, \mathrm{H}-7), 5.11(1 \mathrm{H}, \mathrm{d}, J=9.5 \mathrm{~Hz}, \mathrm{H}-15), 4.30(1 \mathrm{H}, \mathrm{dd}, J=11.0,2.5 \mathrm{~Hz}, \mathrm{H}-$ $\left.1^{\prime} \mathrm{a}\right), 4.14\left(1 \mathrm{H}, \mathrm{d}, J=<1, \mathrm{H}-1^{\prime \prime}\right), 3.99$ (1H, dd, $\left.J=11.0,6.5, \mathrm{H}-1^{\prime} \mathrm{b}\right), 3.89(1 \mathrm{H}, \mathrm{d}$, $J=8.5, \mathrm{H}-13$ ), 3.72 (1H, ddd, $\left.J=9.0,7.0,2.5, \mathrm{H}-2^{\prime}\right), 3.66$ (2H, m, H-5, H-6"b), 3.59 ( $\left.1 \mathrm{H}, \mathrm{dd}, J=11.0,3.0, \mathrm{H}-5^{\prime} \mathrm{a}\right), 3.52\left(2 \mathrm{H}, \mathrm{m}, \mathrm{H}-9, \mathrm{H}-2^{\prime \prime}\right), 3.35-3.47(4 \mathrm{H}, \mathrm{m}$, H-6" a, H-3', H-4', H-5'b), 3.25 ( $\left.1 \mathrm{H}, \mathrm{t}, J=9.5, \mathrm{H}-4^{\prime \prime}\right), 3.15$ ( $1 \mathrm{H}, \mathrm{dd}, J=9.5,3.0$, $\left.\mathrm{H}-3^{\prime \prime}\right), 2.85$ ( $1 \mathrm{H}$, ddd, $\left.J=9.5,6.5,2.5, \mathrm{H}-5^{\prime \prime}\right), 2.56(2 \mathrm{H}, \mathrm{m}, \mathrm{H}-4$ and $\mathrm{H}-12), 2.50$ (overlapping with solvent, $\mathrm{H}-16), 2.42(1 \mathrm{H}, \mathrm{m}, \mathrm{H}-8), 1.78$ and $1.77(3 \mathrm{H}, \mathrm{d}$, $J=1.5 \mathrm{~Hz}, \mathrm{H}-21), 1.55$ (3H, s, H-23), 1.53 (3H, s, H-25), 1.50 (3H, s, H-27), $0.90(3 \mathrm{H}, \mathrm{d}, J=7.0 \mathrm{~Hz}, \mathrm{H}-28), 0.80,(3 \mathrm{H}, \mathrm{t}, J=7.5 \mathrm{~Hz}, \mathrm{H}-20), 0.79(3 \mathrm{H}, \mathrm{d}$, $J=7.0 \mathrm{~Hz}, \mathrm{H}-29), 0.75(3 \mathrm{H}, \mathrm{d}, J=6.5 \mathrm{~Hz}, \mathrm{H}-26), 0.68(3 \mathrm{H}, \mathrm{d}, J=7.0 \mathrm{~Hz}, \mathrm{H}-24)$; ${ }^{13} \mathrm{C}-\mathrm{NMR}$ (DMSO- $\left.d_{6}, 125 \mathrm{MHz}\right) \delta 167.7$ and $167.4(\mathrm{C}-1), 146.7$ and 146.5 (C-3), 137.7 (C-15), 136.1 and 136.0 (C-6), 135.6 (C-10), 131.4 (C-7), 130.7 (C-11), 129.9 (C-14), 126.6 and $126.5(\mathrm{C}-2), 96.2\left(\mathrm{C}-1^{\prime \prime}\right), 85.7$ (C-13), 81.2 (C9), 80.9 and $80.8(\mathrm{C}-5), 77.8\left(\mathrm{C}-5^{\prime \prime}\right), 74.2\left(\mathrm{C}-3^{\prime \prime}\right), 71.0 \times 2,70.8,70.4,68.6,67.4$ (C-4), 67.3, $67.1\left(\mathrm{C}-1^{\prime}\right), 66.1,63.6,62.8,61.3\left(\mathrm{C}-6^{\prime \prime}\right), 44.1$ (C-17), 36.9 (C-4), 36.1 (C-8), 33.8 (C-12), 32.1 (C-18), 29.9 (C-19), 29.4 (C-16), 21.8 (C-28), 18.8 (C-29), 17.5 (C-24), 17.2 (C-26), 16.5 (C-22), 12.6 (C-21), 11.4, $11.2(\times 2), 11.1$ (C-20, C-23, C-25, C-27); HRESIFTMS $m / z 792.5088\left[\mathrm{M}+\mathrm{NH}_{4}\right]^{+}$(calcd for $\left.\mathrm{C}_{40} \mathrm{H}_{74} \mathrm{NO}_{14}, 792.5109\left[\mathrm{M}+\mathrm{NH}_{4}\right]^{+}\right)$.

\section{Roselipins 3C, 3D and 3E (3-5)}

White solid: ${ }^{1} \mathrm{H}-\mathrm{NMR}\left(\mathrm{DMSO}-d_{6}, 500 \mathrm{MHz}\right) \delta 6.67(1 \mathrm{H}, \mathrm{d}, J=9.5 \mathrm{~Hz} . \mathrm{H}-3)$, $5.23(1 \mathrm{H}, \mathrm{d}, J=8.5 \mathrm{~Hz}, \mathrm{H}-11), 5.17(1 \mathrm{H}, \mathrm{d}, J=8.5 \mathrm{~Hz}, \mathrm{H}-7), 5.11(1 \mathrm{H}, \mathrm{d}$, $J=9.5 \mathrm{~Hz}, \mathrm{H}-15$ ), $5.00\left(\mathrm{H}, \mathrm{ddd}, J=7.5,5.5,2.0 \mathrm{~Hz}, \mathrm{H}-2^{\prime}\right.$ or $\mathrm{H}-4^{\prime}$ (for $\mathrm{H}-2^{\prime}$ or $\mathrm{H}-4^{\prime}$ ester) $), 4.82\left(\mathrm{H}, \mathrm{dd}, J=7.5,2.0 \mathrm{~Hz}, \mathrm{H}-3^{\prime}\right.$ for $\mathrm{H}-3^{\prime}$ ester), 4.78 ( $\mathrm{H}$, ddd, $J=7.5,4.5,3.0 \mathrm{~Hz}, \mathrm{H}-2^{\prime}$ or $\mathrm{H}-4^{\prime}$ (for $\mathrm{H}-2^{\prime}$ or $\mathrm{H}-4^{\prime}$ ester) $), 4.14(1 \mathrm{H}, \mathrm{d}, J<2 \mathrm{~Hz}$, $\left.\mathrm{H}-1^{\prime \prime}\right), 3.88$ (1H, d, J=8.5, H-13), 3.65 (2H, m, H-5, H-6" b), 3.52 (2H, m, H-9, $\left.\mathrm{H}-2^{\prime \prime}\right)$, 3.35-3.47 (m, H-6"a, arabinitol protons), $3.24\left(1 \mathrm{H}, \mathrm{t}, J=9.5, \mathrm{H}-4^{\prime \prime}\right)$, $3.14\left(1 \mathrm{H}, \mathrm{dd}, J=9.5,3.0, \mathrm{H}-3^{\prime \prime}\right), 2.84\left(1 \mathrm{H}\right.$, ddd, $\left.J=9.0,6.5,2.0, \mathrm{H}-5^{\prime \prime}\right), 2.55$ $(2 \mathrm{H}, \mathrm{m}, \mathrm{H}-4$ and $\mathrm{H}-12), 2.50$ (overlapping with solvent, $\mathrm{H}-16), 2.42(1 \mathrm{H}, \mathrm{m}$, $\mathrm{H}-8), 1.76(3 \mathrm{H}, \mathrm{d}, J=1.5 \mathrm{~Hz}, \mathrm{H}-21), 1.54(3 \mathrm{H}, \mathrm{s}, \mathrm{H}-23), 1.53(3 \mathrm{H}, \mathrm{s}, \mathrm{H}-25)$, $1.49(3 \mathrm{H}, \mathrm{s}, \mathrm{H}-27), 0.90(3 \mathrm{H}, \mathrm{d}, J=6.5 \mathrm{~Hz}, \mathrm{H}-28), 0.80,(3 \mathrm{H}, \mathrm{t}, J=7.5 \mathrm{~Hz}, \mathrm{H}-20)$, $0.78(3 \mathrm{H}, \mathrm{d}, J=7.5 \mathrm{~Hz}, \mathrm{H}-29), 0.75(3 \mathrm{H}, \mathrm{d}, J=6.5 \mathrm{~Hz}, \mathrm{H}-26), 0.68(3 \mathrm{H}, \mathrm{d}$, $J=6.5 \mathrm{~Hz}, \mathrm{H}-24$ ); HRESIFTMS (as mixture of 3-5) $\mathrm{m} / z$ 792.5095 $\left[\mathrm{M}+\mathrm{NH}_{4}\right]^{+}$ (calcd for $\mathrm{C}_{40} \mathrm{H}_{74} \mathrm{NO}_{14}, 792.5109\left[\mathrm{M}+\mathrm{NH}_{4}\right]^{+}$).

\section{Biological assay}

The in vitro assay against $H$. contortus was performed as described by Michael et al. ${ }^{2}$ The in vivo mouse assay was modified from Fonseca-Salamanca et al. ${ }^{3}$ and performed as follows: Swiss Webster mice $(\sim 30 \mathrm{~g})$ were inoculated with 200-400 L3 H. polygyrus larvae. The mice were checked for infection around day 12 after inoculation, then dosed intramuscularly with test compound in triplicate. On day 3 after treatment, mice were killed and the intestine was 
collected (from below stomach to above cecum), opened, and placed in $5 \mathrm{ml}$ of sterile water. Mucosa was scraped and rinsed through a 200-mesh screen. The rinsate was then examined for presence of worms, and worms were counted. Worm counts for treated mice were then compared with infected, untreated mice as negative controls and infected mice treated with ivermectin $\left(5 \mathrm{mg} \mathrm{kg}^{-1}\right)$ as positive controls.

1 McKellar, Q. A. \& Jackson, F. Veterinary anthelmintics: old and new. Trends. Parasitol. 20, 456-461 (2004).

2 Michael, B., Meinke, P. T. \& Shoop, W. Comparison of ivermectin, doramectin, selamectin, and eleven intermediates in a nematode larval development assay. J. Parasitol. 87, 692-696 (2001).

3 Fonseca-Salamanca, F., Martinez-Grueiro, M. M. \& Martinez-Fernandez, A. R. Nematocidal activity of nitazoxanide in laboratory models. Parasitol. Res. 91, 321-324 (2003).

4 Ayers, S., Zink, D. L., Brand, R., Pretorius, S., Stevenson, D. \& Singh, S. B. Struthiolanone: a flavanone-resveratrol adduct from Struthiola argentea. Nat. Prod. Commun. 3, 189-192 (2008).

5 Ayers, S. et al. Anthelmintic macrolactams from Nonomuraea turkmeniaca MA7364. J. Nat. Prod. 70, 1371-1373 (2007).

6 Ayers, S. et al. Scutiaquinones a and b, perylenequinones from the roots of Scutia myrtina with anthelmintic activity. J. Nat. Prod. 70, 425-427 (2007).

7 Ayers, S. et al. Anthelmintic activity of aporphine alkaloids from Cissampelos capensis. Planta Med. 73, 296-297 (2007).

8 Ayers, S. et al. Anthelmintic macrolactams from Nonomuraea turkmeniaca MA7381. J. Antibiot. 61, 59-62 (2008).

9 Ayers, S. et al. Noreupenifeldin, a tropolone from an unidentified ascomycete. J. Nat. Prod. 71, 457-459 (2008).
10 Ayers, S. et al. Flavones from Struthiola argentea with anthelmintic activity in vitro. Phytochem. 69, 541-545 (2008).

11 Savoie, J. Y. \& Brassard, P. Preparation de quelques cyclohexène-2 diones-1,4 et de leurs dérivés. Can. J. Chem. 49, 3515-3523 (1971).

12 Roth, L. \& Rupp, G. Roth Collection of Natural Products Data. ed. 1-142. (VCH: Weinheim, 1995. ) Vol. II.

13 Kohno, J. et al. Isolation and structure determination of TMC-151s: novel polyketide antibiotics from Gliocladium catenulatum Gilman \& Abbott tc 1280. Tetrahedron 55, 7771-7786 (1999).

14 Kohno, J. et al. TMC-171A,B,C and TMC-154, novel polyketide antibiotics produced by Gliocladium sp. TC 1304 and TC 1282. J. Antibiot. 52, 1114-1123 (1999).

15 Omura, S., Tomoda, H., Tabata, N., Ohyama, Y., Abe, T. \& Namikoshi, M. Roselipins, novel fungal metabolites having a highly methylated fatty acid modified with a mannose and an arabinitol. J. Antibiot. 52, 586-589 (1999).

16 Tabata, N., Ohyama, Y., Tomoda, H., Abe, T., Namikoshi, M. \& Omura, S. Structure elucidation of roselipins, inhibitors of diacylglycerol acyltransferase produced by Gliocladium roseum KF-1040. J. Antibiot. 52, 815-826 (1999).

17 Tomoda, H. et al. Roselipins, inhibitors of diacylglycerol acyltransferase, produced by Gliocladium roseum KF-1040. J. Antibiot. 52, 689-694 (1999).

18 Kasai, Y., Komatsu, K., Shigemori, H., Tsuda, M., Mikami, Y. \& Kobayashi, J. Cladionol a, a polyketide glycoside from marine-derived fungus Gliocladium species. J. Nat. Prod. 68, 777-779 (2005).

19 Inokoshi, J., Kawamoto, K., Takagi, Y., Matsuhama, M., Omura, S. \& Tomoda, H. Expression of two human Acyl-Coa: diacylglycerol acyltransferase isozymes in yeast and selectivity of microbial inhibitors toward the isozymes. J. Antibiot. 62, 51-54 (2009).

20 Singh, S. B. et al. Isolation, structure, and HIV-1-integrase inhibitory activity of structurally diverse fungal metabolites. J. Ind. Microbiol. Biotechnol. 30, 721-731 (2003).

21 Bills, G. F. \& Polishook, J. D. Abundance and diversity of microfungi in leaf-litter of a lowland rain-forest in costa-rica. Mycologia 86, 187-198 (1994).

22 Schroers, H. J. A monograph of bionectria ascomycota, hypocreales, bionectriaceae and its clonostachys anamorphs. Studies Mycol. 46, 1-214 (2001). 